\title{
Accountability and Herding Bias: An Experimental Study on Audit Fraud Judgement
}

\author{
Suzy Novianti ${ }^{1}$, Keviniana Pangarsi Tunbonat ${ }^{2}$, Intiyas Utami ${ }^{3}$ \\ \{suzy.noviyanti@staff.uksw.edu ${ }^{1}, 232015105 @$ student.uksw.edu $^{2}$, intiyas@ @staff.uksw.edu ${ }^{3}$ \} \\ Satya Wacana Christian University, Jalan Diponegoro Nomor 52-60, 50711 \\ Salatiga, Central Java, Indonesia ${ }^{1,2,3}$
}

\begin{abstract}
Auditors' behavior and attitude likely affect their judgments in determining fraud risks. As suggested by previous studies, an important auditor behavior is accountability that arguably affects auditors' judgment. Together with herding behavior, accountability likely affects audit fraud judgment. This study aims to examine the effects of accountability and herding behavior on audit fraud judgment. As quantitative research, this study uses a $2 \times 2$ between-subjects experimental design. The subjects are 79 external auditors in Central Java Province. The results show that both accountability and herding affect audit fraud judgment. Additionally, the paper also demonstrates that auditors with high (low) accountability and low (high) herding behavior exhibit the best (worst) audit fraud judgment. Thus, this study suggests that partner auditors need to ensure that their auditors exhibit disciplined behaviors. Also, this paper implies that auditors need to protect their independence and to be less affected by others' opinions.
\end{abstract}

Keywords: accountability, herding, audit fraud judgment

\section{Introduction}

Firms are obliged to prepare financial statements for their internal and external stakeholders. Financial statements help investors, creditors, governments, and other stakeholders make decisions. The requirement to prepare financial statements is stipulated by BAPEPAM Regulation No. Kep-36/PM/2003 and Jakarta Stock Exchange (BEJ) Regulation No. Kep-306/ BEK/07-2004. Both regulations require firms listed at the Indonesian Stock Exchange (BEI) to submit audited financial statements that comply with the Indonesian Financial Accounting Standards (Standar Akuntansi Keuangan - SAK).

External auditors' independence in performing audit is instrumental to ensure that financial statements are reliable, relevant, and accurate. An important role of external auditors is making audit judgments. Audit judgments consist of several categories, including audit fraud judgment. External auditors' judgment will affect fraud-related audit results in responding to the existing audit evidence. External auditors must generate sufficient confidence that financial statements are free from material misstatements due to errors or frauds (Ikatan Akuntan Publik Indonesia, 2016).

External auditors should make audit fraud judgments according to existing field conditions because such judgments will affect their final opinion on the fairness of audited financial statements. Audit fraud judgments that are not in line with the existing conditions will affect organizations' reputation with their stakeholders. External auditors work in organizations with various interests. Consequently, external auditors are potentially affected by their surrounding environments and tend to imitate existing behavior. This condition is often called as herding. For auditors, mimic is a negative behavior because it motivates them not to implement independence and professional skepticism in making judgments.

Besides herding, another factor that potentially affects audit fraud judgment is accountability. Accountability significantly affects audit judgment because auditors are responsible to their superiors (Hoffman dan Patton, 1997). Accountability helps auditors account for their final opinions to their clients. External auditors' accountability and herding likely affect auditors' judgments in detecting frauds that potentially lead to audit failure.

A notable audit failure in detecting fraud involves British Telecom and PwC. As an audit client, British Telecom is a multinational firm that experienced accounting frauds. As the auditor, Price 
Waterhouse Coopers (PwC), a big-four accounting firm, failed to detect the frauds. The failure eroded the reputation of $\mathrm{PwC}$ and even of public accountant profession in general. Specifically, the Italian business line of British Telecom conducted accounting frauds by inflating profits for several years by making agreements with several clients and financial services through corruption. Consequently, British Telecom had to cut its projected cash flows of GBP 500 million to pay previously unreported liabilities.

Several factors affect auditors' judgment in detecting frauds. Carpenter dan Reimers (2013) argue that professional skepticism identifies fraud risk factors. Hammersley (2011) identifies that auditors need fraud knowledge to help them make audit judgments in detecting frauds. Besides, Putri et al., (2013) empirically find that independence, experience, due professional care, accountability, and time budget pressure simultaneously affect audit quality. Auditors with a high level of accountability fully commit to their assignments that will affect audit results. Based on several factors that affect audit judgments, accountability is a variable that affects auditors' judgment in detecting frauds.

Individuals' behavior is closely related to their groups or environments because of their subjective norms or mindsets as a response to social pressures to commit or not to commit certain behaviors that are commonly labeled as herding. Studies on herding behavior commonly use investors as their research context. For example, Tristyanto (2014) empirically show that herding is affected by the perspectives of various investor types. Further, Gozalie dan Anastasia (2015) demonstrate that heuristic and herding behaviors affect investment decisions of residential properties. Also, Litimi (2017) analyzes herding behavior in the French stock market. Herding also potentially exists in the audit context of public accountants. Public accountants must make audit judgments professionally. However, as individuals with bounded rationality, they also potentially experience herding. In this respect, their audit judgments are likely affected by their surrounding environments.

This study aims to investigate the causal relationship between accountability and herding and audit fraud judgment. Thus, this study informs audit firms' top management and external auditors' behavioral factors that affect audit fraud judgments. Besides, future studies can refer to this paper in analyzing the relationships between accountability, herding, and audit fraud judgment.

\section{Literature Review and Hypothesis Development}

\subsection{Accountability}

Mardisar dan Sari (2007) define accountability as an individuals' internal motivation to account for their actions to external parties (environment, society, and other parties). Tetlock dan Kim (1987) explain that accountability is an attitude to predict individual behavior more accurately. Besides, accountability also refers to auditors' attitude and ability to explain all audit procedures more detailed and to answer all questions and to provide explanations to clients (Salsabila \& Prayudiawan, 2011). It then can be concluded that accountability is a responsible behavior to produce more accurate and accountable outputs.

Accountability affects judgment making process because it reflects the relationship between individuals and their surrounding environments (Tetlock, 1992). Besides, accountable attitude requires individuals' motivation to utilize their knowledge and skills to make decisions (Tetlock, 1992). When external auditors exhibit a high degree of accountability, they are likely to make fraud judgments more accurately (Schafer, 2007). In accounting, auditors use relevant information in making judgments. Accountability emphasizes good judgments that it requires prudence and internal motivation to make judgments because such judgments affect their stakeholders.

Meanwhile, Aji (2009) identifies three indicators to measure accountability, namely motivation, dedications to the profession, and social responsibility. Motivation is the individuals' internal urge to commit a certain act to achieve their objectives. A dedication to the profession is a commitment that reflects professionalism to work totally. Lastly, social responsibility emphasizes the importance of the profession's role to the public and surrounding environments.

\subsection{Herding}

Herding is an individual tendency to imitate behaviors of a group of a larger number of other individuals (Subash, 2012). In the accounting context, herding is the external auditors' behavior that imitates their surrounding environments in making judgments. Herding behavior can make both positive and negative consequences. However, this study largely focuses on the negative effect of herding on 
external auditors' judgments in detecting frauds in their clients. Specifically, it is likely that low herding negatively affects external auditors' audit fraud judgments. External auditors' herding behavior will negatively affect their fraud judgments because of the lack of independence in performing audits. Herding behavior will erode individuals' self-confidence in making decisions. Individuals will arguably perceive that imitating what others act will enhance the likelihood of being accepted by their surrounding environments likely because of their cognitive limitations in making judgments.

Setiyono et al., (2013) identify three factors that are closely related to herding, namely information-based herding, informational acquisition herding, and reputation and compensation herding. Information-based herding is a condition where individuals observe and learn the behavior of their surrounding environments under uncertain conditions. Next, informational acquisition herding occurs when investors receive the same information and decide to buy or sell assets similarly to other investors' decisions. Lastly, reputation and compensation herding refers to a condition where investors tend to follow other investors' behavior because they receive imperfect information for various reasons, such as to protect their reputation, to advance their careers, and to generate certain compensation.

\subsection{Audit Fraud Judgement}

Auditors are accountable for generating sufficient confidence and expressing opinions about whether financial statements are free from material misstatements due to errors or frauds (Ikatan Akuntan Publik Indonesia, 2016). Errors are unintentional while frauds are committed by highly conscious individuals. Financial statements frauds consist of intentional misstatements and the omissions of amounts or disclosures to mislead financial statement users

(Arens, Randal, \& Beasley, 2015). Three factors encourage individuals to commit frauds, namely pressure, opportunity, and rationalization. Pressure refers to financial and emotional powers to motivate frauds. Opportunity is the chance to execute plans without being known by others. Lastly, rationalization refers to individuals' justification to act dishonestly (Association of Certified Fraud Examiners (ACFE), 2018).

Auditors need to detect three types of frauds in audit procedures, namely corruption, asset misappropriation, and financial statement frauds. External auditors focus on financial statement frauds to determine the materiality of the frauds. Further, there are three modes of financial statement frauds. Firstly, fraudsters manipulate, falsify, or change accounting records or documents that serve as the basis of preparing financial statements. Secondly, fraudsters make erroneous statements or intentionally delete significant events, transactions, or information from financial statements. Thirdly, fraudsters intentionally make the erroneous implementation of accounting principles concerning the amount, classification, presentation, or disclosure (Ikatan Akuntan Publik Indonesia, 2016). Concerning audit fraud judgment, auditors determine the fraud risk level of clients by analyzing fraud types. External auditors' consideration in detecting frauds is their decisions that are related to the estimation of fraud risk and the modification of audit procedures (Hammersley, 2011).

\subsection{The Effect of Accountability and Audit Fraud Judgment}

Accountability refers to an attitude that is responsible for one's decision. Auditors are responsible for making judgments, including fraud-related ones. Schafer (2007) shows consistent results that accountability likely affects auditors' judgment by affecting audit evidence as to the basis of making audit judgments. Auditors are internally motivated to detect clients' frauds to demonstrate that they perform audits responsibly. This motivation is affected by auditors' internal beliefs to produce opinions that better reflect clients' real situation. Besides, commitment when performing audit procedures also affects auditors' accountability. An indicator that measures one's accountability is the dedication to the profession. Auditors' professional ethics enable auditors to perform totally in auditing frauds. Auditors play a significant role in society and audited firms because audit opinion affects clients' reputation.

According to Putri et al. (2013), independence, experience, due professional care, accountability, and time budget pressure simultaneously affect audit quality. Audit quality is also affected by auditors' fraud judgment. Audit quality will increase if auditors make correct fraud judgment. As suggested by Hoffman dan Patton (1997), accountability is a factor that significantly affects auditors' judgments because auditors are required to account for their judgments to their superiors that will potentially lead to fraud risk in giving audit opinions. Thus, auditors' accountability will likely affect audit fraud judgments. 
H1: Auditors with high accountability will make audit fraud judgments that are in line with clients' actual condition.

\subsection{The Relationship between Herding and Audit Fraud Judgment}

Herding refers to a behavior that imitates surrounding environments. Auditors are required to make judgments to assess their clients. When making judgments, external auditors likely consider previous auditors' judgments. Besides, external auditors can also make judgments based on clients' surrounding environments and even the influence of clients' management. This condition potentially erodes external auditors' independence and professional skepticism.

Andhika dan Damayanti (2017) argue that individuals' perception of social pressures to commit or not to commit certain actions likely leads to herding, and it is a subjective norm. In other words, when individuals interact more frequently with other individuals in certain groups, they are more likely to behave similarly to other individuals in these groups. When external auditors are under social pressures from their environments, herding will occur to motivate external auditors to make generally accepted decisions. External auditors make numerous decisions, including estimating clients' fraud risk. Herding may negatively affect the decision process when external auditors make fraud judgments that are not in line with clients' real condition due to external influences. For example, when external auditors are affected by herding, they are likely to assess fraud risk low by considering unqualified opinions of previous auditors.

No previous studies investigate the relationship between herding and audit fraud judgment. However, Tristyanto (2014) have investigated the relationship between the herding variable with investor type. Meanwhile, Gozalie dan Anastasia (2015) empirically find that herding affects investment decisions on residential properties. Andhika dan Damayanti (2017) also investigate herding and show that herding positively affects SME owners' intention to maintain accounting records. This study investigates the relationship between herding and audit fraud judgment.

$\mathrm{H} 2$ : Auditors with low herding will make audit fraud judgments that are in line with clients' actual condition.

\subsection{The Relationship between Accountability and Herding and Audit Fraud Judgment}

Auditors need a high accountability behavior to detect frauds and to determine risk levels because auditors are motivated by a high confidence level to perform audit procedures and to complete assignments optimally. Meanwhile, individuals are social creatures who are always connected with others in their surrounding environments. This fact may lead to a negative effect if auditors are constantly affected by others when making decisions. Consequently, auditors become less independent and skeptical in detecting existing frauds.

Auditors' accountability is crucial to perform audit procedures. Accountability facilitates auditors to perform their assignments responsibly and to make good judgments. Judgments that represent real condition will affect audit quality. Several factors affect audit quality, including auditors' client tenure as the span of the engagement between audit firms and clients (Werastuti, 2013). A longer tenure may lead auditors to prioritize management's interests over theirs. Also, a longer tenure may cause auditors to exhibit high herding when making judgments that eventually reduces their independence and skepticism. Herding occurs when auditors highly take clients, previous auditors, and even surrounding environments into account.

Putri et al. (2013) argue that independence, experience, due professional care, accountability, and time budget pressure simultaneously affect audit quality. However, no previous studies analyze the herding variable and its relationship with audit fraud judgment. It is then predicted that accountability and herding are related in affecting audit fraud judgment. Besides, the relationship between the independent variables is more dominant in affecting judgments. Thus, more accountable auditors with lower herding are likely to make better audit fraud judgments.

H3: Auditors with low herding but high accountability towards their assignments will make audit fraud judgments that are in line with clients' actual condition. 


\section{Research Methods}

This study uses a $2 \times 2$ factorial experiment design. The subjects are senior auditors and supervisors at public accounting firms in Central Java area. The dependent variable is audit fraud judgment, and the independent variables are accountability and herding. This study relies on the experimental method because it offers a higher degree of internal validity in testing the relationship between the dependent and independent variables. Besides, an experimental study can control for other variables.

Accountability is defined as individuals' internal drive to account for their actions to external parties (e.g., environments, society) (Mardisar dan Sari, 2007). Herding refers to a condition where auditors imitate the beliefs of management, previous auditors, and their surrounding environment when determining audit fraud judgments.

Table 1. Research Matrix

\begin{tabular}{lccc}
\hline & & \multicolumn{2}{c}{ Herding } \\
\cline { 3 - 4 } & & Low & High \\
\hline \multirow{2}{*}{ Accountability } & Low & Group 1 & Group 2 \\
& High & Group 3 & Group 4 \\
\hline
\end{tabular}

Explanation:

Cell 1: Low accountability and low herding.

Cell 2: Low accountability and high herding.

Cell 3: High accountability and low herding.

Cell 4: High accountability and high herding.

The experiment conditioned high accountability by illustrating three cases that were related to the three accountability indicators. For the motivation indicator, the study conditioned the participants to have a high self-confidence (high accountability) and low self-confidence (low accountability). For the dedication to profession indicator, participants were conditioned that the audit firm where participants work was very disciplined in reporting (high accountability) and was tolerant or implemented code of ethics/ rule flexibly (low accountability). Next, for the third indicator or social responsibility, the experiment conditioned participants by informing that the society and stakeholders paid much attention to them and used their audit reports as a basis of decision making (high accountability). For the low accountability condition, the society and stakeholders did not observe the client's financial statements more detailed and did not use financial statements for their decision making.

In this experiment, herding measured individual bias by distributing questionnaires to participants. Each answer would be standardized. The scores that were above the average would be classified as high herding. Conversely, scores below the average would be classified as low herding. The study tested the herding variable by asking participants 8 questions on participants' innate behavior that were related to fraud-detecting decisions. The questions would be measured with 4-point Likert scale.

The audit situation that was presented was a fraud case that was related to a profit overstatement through fictitious sales and purchases that were both interrelated. The case was subsequently associated with each participant's condition in the accountability variable. Participants would assess the fraud risk level and decide the subsequent phase related to the search of subsequent audit evidence.

As an employee of an audit firm, subjects were assigned to audit highly reputable PT Indomart. The presented case design was that PT Indomart was highly reputable by investors and had a high share price. The company was also well known for its social responsibility to the public. The experimenters would guide participants to fill in the pre-test twice. The first pre-test dealt with the knowledge of audit fraud judgments in the form of questions. Meanwhile, the second pre-test asked subjects about companyrelated questions. Next, subjects would receive a case that was designed that facilitated subjects to m0ake decisions. Specifically, subjects were required to assess their decisions that were related to fraud audit. Subjects made decisions by the scoring of 1-10. A score that was close to 10 indicated a good audit fraud judgment and vice versa.

The following are the analysis phases in this study: (1). Presenting the descriptive statistics from the experiment; (2). Running the randomization check by using one-way Analysis of Variance (onway 
ANOVA); (3). Performing the manipulation check to identify which data qualified or no; and (4). Testing the hypotheses by using the t-test for the first and second hypotheses to analyze the individual effects of the independent variables on audit fraud judgment. For the third hypothesis, the study relied on two-way analysis of variance (two-way ANOVA) to test the relationship of the two independent variables in affecting the dependent variable and to identify which independent variable affects more. The hypothesis would be empirically supported if the significance value is less than 0.05 .

\section{Results and Discussion}

\subsection{Subjects' Descriptive Statistics}

The experiment was held in a training session for auditors in Central Java area on August 27, 2018, at Hotel Patra Jasa Semarang. There were 70 auditors participated in this experiment. However, six of them did not fill in the participant profile completely, resulting in 64 participants with usable responses.

Table 2. Respondents' Characteristics

\begin{tabular}{|c|c|c|}
\hline Explanation & Total & Percentage \\
\hline \multicolumn{3}{|l|}{ Age: } \\
\hline 20-30 years & 9 & $14.06 \%$ \\
\hline $30-40$ years & 17 & $26.56 \%$ \\
\hline 40-50 years & 19 & $29.69 \%$ \\
\hline 50-70 years & 19 & $29.69 \%$ \\
\hline Total & 64 & $100 \%$ \\
\hline \multicolumn{3}{|l|}{ Sex: } \\
\hline Male & 47 & $73.44 \%$ \\
\hline Female & 17 & $26.56 \%$ \\
\hline Total & 64 & $100 \%$ \\
\hline \multicolumn{3}{|c|}{ Working Experience: } \\
\hline $1-10$ years & 24 & $37.5 \%$ \\
\hline 10-20 years & 21 & $32.81 \%$ \\
\hline 20-30 years & 19 & $29.69 \%$ \\
\hline Total & 64 & $100 \%$ \\
\hline \multicolumn{3}{|c|}{ Highest Education: } \\
\hline Bachelor & 32 & $50 \%$ \\
\hline Master & 25 & $39.06 \%$ \\
\hline Doctorate & 7 & $10.93 \%$ \\
\hline Total & 64 & $100 \%$ \\
\hline
\end{tabular}

Source: Processed primary data (2019)

\subsection{Manipulation Checks}

Table 3 explains the manipulation checks. The first manipulation check focused on subjects' understanding of their role and task using five questions. Subjects qualified if they answered at least three questions correctly. Next, the manipulation check on the accountability treatment was measured with a 
scale of 1-10 with the theoretical mean of 5. For subjects who received high accountability treatment, they would qualify if they score more than 5 (the theoretical mean). On the contrary, subjects with low accountability treatment would qualify if they scored below 5. Further, the manipulation check of herding asked respondents six questions with a scale of 1-4. Subjects with the high (low) herding manipulation would qualify if their score were below (above) the population mean.

Table 3. Manipulation Checks

\begin{tabular}{llll}
\hline No & \multicolumn{1}{c}{ Explanation } & N & Results \\
\hline $\mathbf{1}$ & $\begin{array}{l}\text { Understanding the task and role in the } \\
\text { experiment (5 questions) }\end{array}$ & 64 & 64 \\
$\mathbf{2}$ & Accountability & 64 & 64 \\
$\mathbf{3}$ & Herding & 64 & 64 \\
$\mathbf{4} \quad \begin{array}{l}\text { Total participants after the manipulation } \\
\text { check }\end{array}$ & 64 & 64 \\
\hline & &
\end{tabular}

Table 3 informs that all participants passed the manipulation checks of understanding on task and role, accountability, and herding. Thus, all 64 participants managed to participate in the subsequent phase.

\subsection{Randomization Check}

This study used one-way ANOVA to run the randomization check. Randomization check analyzed and ensured that subjects' audit fraud judgments were not affected by their demographic factors such as age, sex, working experience, and highest educational level.

Table 4. One-Way ANOVA Test

\begin{tabular}{lcccc}
\multicolumn{5}{c}{ Table 4. One-Way ANOVA Test } \\
\hline & Mean Square & F & Sig & Explanation \\
\hline Age: & 4.267 & 0.864 & 0.465 & No Effect \\
Between Groups & 4.937 & & & \\
Within Groups & & & & No Effect \\
Sex: & 4.289 & 0.873 & 0.354 & \\
Between Groups & 4.915 & & & No Effect \\
Within Groups & & & & \\
Working Experience: & 7.661 & 1.591 & 0.212 & No Effect \\
$\quad$ Between Groups & 4.815 & & & \\
Within Groups & & & & \\
Highest Education: & 11.944 & 2.555 & 0.086 & \\
Between Groups & 4.675 & & & \\
Within Groups & & & & \\
\hline
\end{tabular}

Source: SPSS (version 22) Output

Table 4 displays the outputs of one-way ANOVA. Specifically, the table suggests that the tests of subjects' demographic factors (age, sex, working experience, and highest educational level) exhibit significance values greater than 0.05 (alpha). It then can be concluded that the audit fraud judgment variable was only affected by the experimental treatments and not by subjects' demographic factors. 


\subsection{Test of Hypothesis 1}

The first hypothesis of this study predicts that auditors with higher accountability will make audit fraud judgments that are more in line with clients' actual condition than auditors with lower accountability. The following Table 5 shows the results of hypothesis 1 testing.

Table 5. The Results of Hypothesis 1 Testing

\begin{tabular}{|c|c|c|c|c|}
\hline & Mean & Std. Deviation & $\mathbf{F}$ & Sig. (2-tailed) \\
\hline \multicolumn{5}{|c|}{ Accountability } \\
\hline High & 7.708 & 1.439 & & \\
\hline Low & $744^{4}$ & 1.834 & 2.192 & 0.000 \\
\hline
\end{tabular}

Source: SPSS (version 22) Output

The results show that the significance value is less than 0.05 (alpha), suggesting that auditors' accountability affects audit fraud judgment. The table also demonstrates that the mean value of audit fraud judgments of subjects with the high (low) accountability treatment is 7.708 (4.744). The figures imply that auditors with high accountability will make audit fraud judgments that are more in line with clients' conditions than those with low accountability.

Subjects in this experiment were required to make judgments by scoring based on the existing information. Specifically, they were required to determine the risk level and to decide whether they would accept or reject to find further audit evidence. Subjects with low accountability would tend not to report the real conditions because their superiors would not give specific punishments or would always tolerate mistakes they made. Subjects would also perceive that the external factors of their stakeholders affect the decision to report or not. Further, auditors who had low accountability would tend to have less responsibility to themselves, their profession, or their clients' stakeholders.

The results of the hypothesis 1 testing are in line with Schafer (2007) and Hoffman dan Patton (2012) who empirically find that accountability likely affects auditors' judgment because accountability affects audit evidence as to the basis of making judgments. Thus, auditors with greater accountability will make audit fraud judgments that better reflect clients' actual condition.

\subsection{Test of Hypothesis 2}

The second hypothesis predicts that auditors with low herding will make audit fraud judgments that better reflect clients' actual condition than auditors with high herding. Table 6 shows the results of the hypothesis testing.

Table 6. The Results of Hypothesis 2 Testing

\begin{tabular}{ccccc}
\multicolumn{5}{c}{ Table 6. The Results of Hypothesis 2 Testing } \\
\hline Mean & $\begin{array}{c}\text { Std. } \\
\text { Deviation }\end{array}$ & F & Sig. (2-tailed) \\
\hline Herding & & & \\
High & 5.514 & 1.672 & 5.681 & 0.006 \\
Low & 7.033 & 2.491 & & \\
\hline \multicolumn{2}{l}{ Source $:$ SPSS (version 22) Output }
\end{tabular}

Table 6 indicates that the significance value of this test is $0.006 \leq 0,05$ (alpha). It then can be interpreted that the herding variable affects audit fraud judgment. The test also finds that the mean value of audit fraud judgments of subjects with high (low) herding is 5.514 (7.033). The results imply that auditors with low herding will make audit fraud judgments that are more in line with clients' real condition than auditors with high herding.

Andhika dan Damayanti (2017) find that subjects with high herding tend to follow their surrounding environments when making decisions. For example, they may base their fraud judgments based on information from the media. Also, subjects with high herding perceive that their findings of audit evidence have been confirmed by previous auditors and compare their findings with the findings of 
previous audits without considering to find further audit evidence. Besides, subjects consider it important to maintain their reputation that will affect their fraud judgments because they will follow the demands of their surrounding environments. These factors erode auditors' independence in assessing fraud risk levels through audit evidence.

These arguments hold when auditors who have to determine risk levels must consider various factors from their surrounding environments. The desire to imitate what occurred previously is greater than the intention to protect auditors' independence that will produce poorer audit fraud judgments. The findings are also in line with Gozalie dan Anastasia (2015) who empirically find that herding affects the investment decisions of residential properties. Thus, herding will affect individuals' decisions that require considerations from their surrounding environments.

\subsection{Test of Hypothesis 3}

The third hypothesis predicts that there is a relationship between the two independent variables (accountability and herding) on audit fraud judgments. Specifically, the hypothesis predicts that auditors with low herding and high accountability towards their assignments make audit fraud judgments that are more in line with clients' actual condition.

Table 7. The Results of Hypothesis 3 Testing

\begin{tabular}{|c|c|c|c|c|c|c|}
\hline & & Mean & $\begin{array}{l}\text { Std. } \\
\text { Deviation }\end{array}$ & $\begin{array}{l}\text { Mean } \\
\text { Square }\end{array}$ & $\mathbf{F}$ & Sig. \\
\hline Hioh & High Herding & 6.594 & 1.057 & & & \\
\hline Accountability & Low Herding & 8.822 & 0.718 & & & \\
\hline \multirow{7}{*}{$\begin{array}{l}\text { Low } \\
\text { Accountability }\end{array}$} & High Herding & 4.555 & 1.539 & & & \\
\hline & Low Herding & 4.988 & 2.192 & & & \\
\hline & Corrected Model & & & 60.580 & 28.552 & 0.000 \\
\hline & Intercept & & & 2472.514 & 1165.302 & 0.000 \\
\hline & Akuntabilitas & & & 136.906 & 64.524 & 0.000 \\
\hline & Herding & & & 28.111 & 13.249 & 0.001 \\
\hline & Akuntabilitas*Herding & & & 12.777 & 6.022 & 0.017 \\
\hline
\end{tabular}

Table 7 informs that the significance value of the relationship between accountability and herding is $0.017 \leq 0,05$. The results indicate the relationship or interaction between accountability, herding, and audit fraud judgments. The mean scores show that subjects with high accountability and low herding exhibit the greatest score, thus indicating that they make audit fraud judgments that reflect best clients' actual conditions compared to other groups.

Subjects with high accountability will make audit fraud judgments that are more in line with clients' actual condition than those with low accountability. Subjects will perceive that they have to report anything they find on the field to their superiors. Thus, accountability is a factor that significantly affects auditors' judgments because auditors are required to be responsible to their superiors that will increase fraud risk in preparing audit results (Hoffman \& Patton, 1997). At the same time, subjects with low herding also make audit fraud judgments that are more in line with clients' actual conditions than those with low herding. Subjects will arguably prioritize their independence over their interests, such as reputation or factors from their surrounding environments.

Subjects who have high accountability and also high herding will make audit fraud judgments that are more in line with the actual condition than subjects with low accountability and low herding. Subjects who consider being responsible to their superiors important, although they also take environmental factors or previous auditors into consideration will make better assessments of fraud risk levels. 


\section{Conclusions, Limitations, Suggestions, And Implications}

The study demonstrates that auditors' accountability and herding affect their audit fraud judgments. The results suggest when auditors have the internal motivation to work responsibly are supported with existing rules, they likely make better judgments in estimating frauds. Besides, the findings also indicate that when auditors imitate less their surrounding environments or other external factors, their audit fraud judgments better reflect field conditions.

Accountability and herding are crucial in making audit fraud judgments that are in line with real conditions. Thus, the top management of audit firms needs to implement rules to their auditors to work disciplined and to report anything found in fields. Besides, they need to provide their auditors with motivational training to enhance auditors' responsibility in working activities. It is expected that auditors maintain their independence and are not affected by other auditors' opinion without sufficient audit evidence as stipulated by the professional code of ethics of public accountant.

This study is subject to several caveats. For example, participants have a too long time to fill in the module that potentially leads to biased answers. It is advised that future studies provide participants a shorter time to fill in the modules. Besides, future studies can expand the scope of research subjects to represent expected results better.

\section{References}

[1]Aji, P. S.: Factors affecting audit quality judging from the auditor's perception of independence, experience, and accountability. Jenderal Soedirman University Purwokerto (2009)

[2]Andhika, Y. H., \& Damayanti, T. W.: Intention to make accounting records in small and medium enterprises: accounting knowledge or herding? Vol 20, pp 331-346. Journal of Economics and Business (2017)

[3]Arens, A., Randal, E., \& Beasley, M. S.: Auditing and services assurance integrated approach. (2015)

[4]Association of Certified Fraud Examiners (ACFE).: Triangle fraud. (2018)

[5]Carpenter, T. D., \& Reimers, J. L.: Professional skepticism: the effects of a partner's influence and the level of fraud indicators on auditors' fraud judgments and actions. pp 45-69. Behavioral Research in Accounting (2013)

[6]Gozalie, S., \& Anastasia, N.: The effect of heuristics and herding behavior on decision making in residential property investment. pp 28-32. Finesta (2015)

[7]Hammersley, J. S.: A review and model of auditor judgments in fraud-related planning tasks. Vol. 30, pp 101-128. Auditing: A Journal of Practice \& Theory (2011)

[8]Hoffman, V. B., \& Patton, J. M.: Accountability, the dilution effect, and conservatism in auditors' fraud judgments. Vol. 35, pp 227-237. Journal of Accounting Research (1997)

[9]Ikatan Akuntan Publik Indonesia PSA 1 (SA 110).: Auditor's responsibilities. (2016)

[10]Kerlinger, F.: Principles of behavioral research. Yogyakarta: Gadjah Mada University Press (1986)

[11]Litimi, H.: Herd behavior in the french stock market. Vol. 16, pp497-515. Emerald Insight (2017)

[12]Mardisar, D., \& Sari, R. N.: Effect of accountability and knowledge of the quality of auditor's work results. (2007)

[13]Peraturan BAPEPAM Nomor Kep-36/PM/2003.: Obligation to submit periodic financial reports. (2003)

[14]Peraturan Bursa Efek Jakarta (BEJ) Nomor Kep-306/BEJ/07-2004.: Obligations for submitting information. (2004)

[15]Putri, R., Nirmala, A., \& Cahyonowati, N.: Effect of independence, experience, due professional care, accountability, audi complexity, and time budget pressure on audit quality (empirical study of KAP auditors in Central Java and DIY). Diponegoro Journal of Accounting (2013)

[16]Salsabila, A., \& Prayudiawan, H.: Effects of accountability; audit and gender knowledge of the quality of internal auditors' work results. Research and Accounting Research Journal (2011)

[17]Schafer, B. A.: Accountability and affect in auditor judgement. (2007)

[18]Sekaran, U.: Reseach methods for busines. Jakarta: Salemba Empat (2008)

[19]Setiyono, Tandelilin, E., Hartono, J., \& Hanafi, M. M.: Detecting the existence of herding behavior in intraday data: evidence from the Indonesian stock exchange. Vol. 15, pp 27-44. Gadjah Mada International Journal of Business (2013)

[20]Subash, R.: Role of behavioral finance in portfolio investment decisions: evidence from India. 
Faculty of Social Science Institute of Economic Studies. (2012)

[21]Tetlock, P. E.: The impact of accountability on judgment and choice: toward a social contingency model. Vol. 25, 331-376. Advances in Experimental Social Psychology (1992)

[22]Tetlock, P. E., \& Kim, J. I.: Accountability and judgment processes in a personality prediction task. Vol 52, pp 700-709. Journal of Personality and Social Psychology (1987)

[23]Tristyanto, R. W.: Herding behavior analysis based on investor type in share ownership. Diponegoro University (2014)

[24]Werastuti, D. N. S.: Effect of tenure client auditor, default debt, reputation auditor, client size and financial condition on quality. Vol. 2, pp 99-116. Vocational Accounting Research Journal (2013) 